\title{
STRATEGI KEPALA SEKOLAH DALAM MENINGKATKAN MUTU PEMBELAJARAN DI SMP NURUL ISLAM KELURAHAN GARUNTANG KECAMATAN BUMI WARAS KOTA BANDAR LAMPUNG
}

\author{
Ani Sari, Eri Purwanti, Moh. Masrur \\ Jl. Raya Wonokriyo Gadingrejo Pringsewu \\ Email: stitpringsewu@gmail.com
}

\begin{abstract}
The purpose of this study was to determine the strategy Principal in improving the quality of learning in junior Nurul Islam Village Garuntang Earth Sane District of Bandar Lampung.

Data analysis is descriptive qualitative analysis that emphasizes the meaning, reasoning, the definition of a given situation (in certain contexts) and describes what about the behavior of the object being studied. Data collector is observation, interview and documentation. As for the conclusions using inductive thinking approach is thought that departs from the facts or specific events later on the facts particular to be withdrawn generalizations that have common properties.

Results and analysis can be concluded that the Headmaster had carried out various strategies to enhance the quality of learning in junior Nurul Islam Village Garuntang District of Earth Sane Bandar Lampung that motivate teachers to be creative and innovative in teaching and learning, include teacher training activities, workshops, seminars and others to increase the knowledge and insights of teachers in education, emphasized discipline in terms of utilization of time learning, creation of learning tools and clothing, supervision (supervision) in the preparation of learning tools as well as in the implementation of learning in the classroom and additional hours of special lessons for the subjects of Islamic education because material is vast.
\end{abstract}

Keywords: Strategy Principal, the quality of learning

\begin{abstract}
Abstrak
Tujuan penelitian ini adalah untuk mengetahui strategi Kepala Sekolah dalam meningkatkan mutu pembelajaran di SMP Nurul Islam Kelurahan Garuntang Kecamatan Bumi Waras Kota Bandar Lampung. analisis data yang digunakan adalah analisa kualitatif deskriptif yaitu analisis data yang menekankan pada makna, penalaran, definisi suatu situasi tertentu (dalam konteks tertentu) serta menggambarkan apa adanya mengenai perilaku obyek yang sedang diteliti. Alat pengumpul data yang digunakan adalah observasi, interview dan dokumentasi. Adapun dalam pengambilan kesimpulan menggunakan pendekatan berfikir induktif yaitu pemikiran yang berangkat dari fakta-fakta atau peristiwa-peristiwa khusus kemudian dari fakta-fakta yang khusus tersebut ditarik generalisasi-generalisasi yang mempunyai sifat umum.

Hasil dan analisis data dapat disimpulkan bahwa Kepala Sekolah telah melakukan berbagai macam strategi dalam meningkatkan mutu pembelajaran di SMP Nurul Islam Kelurahan Garuntang Kecamatan Bumi Waras Kota Bandar Lampung yaitu memotivasi guru untuk kreatif dan inovatif dalam proses belajar mengajar, mengikutkan guru dalam kegiatan pelatihan, workshop, seminar dan lain sebagainya untuk menambah pengetahuan dan wawasan guru dalam dunia pendidikan, menekankan kedisiplinan dari segi pemanfaatan waktu belajar, pembuatan perangkat pembelajaran maupun pakaian, melakukan supervisi (pengawasan) dalam hal penyusunan perangkat pembelajaran maupun dalam pelaksanaan pembelajaran di kelas dan penambahan jam pelajaran khusus untuk mata pelajaran Pendidikan Agama Islam karena materinya sangat luas.
\end{abstract}

Kata kunci : Strategi Kepala Sekolah, mutu pembelajaran 


\section{A. PENDAHULUAN}

Peningkatan mutu pendidikan merupakan sasaran pembangunan di bidang pendidikan nasional dan merupakan bagian integral dari upaya peningkatan kualitas manusia secara menyeluruh. Upaya mencerdaskan kehidupan bangsa menjadi tanggung jawab pendidikan, terutama dalam mempersiapkan peserta didik menjadi subyek yang bertaqwa kepada Tuhan Yang Maha Esa, berakhlak mulia, tangguh, kreatif, mandiri, demokratis, dan professional pada bidangnya masing-masing (Mulyasa, 2005:31). Hal ini sejalan dengan tujuan pendidikan nasional yang tercantum dalam Undang-undang Nomor 20 Tahun 2003 tentang Sistem Pendidikan Nasional, yaitu perlunya pengembangan kemampuan dan pembentukan watak serta peradaban bangsa yang bermartabat untuk mencerdasakn kehidupan bangsa, mengembangkan potensi peserta didik agar menjadi manusia yang beriman dan bertakwa kepada Tuhan Yang Maha Esa, berakhlak mulia sehat, berilmu, cakap, kreatif, mandiri.

Untuk mewujudkan tujuan pendidikan nasional tersebut, salah satu cara yang bisa ditempuh untuk mencapai tujuan pendidikan nasional yaitu melalui peningkatan mutu pembelajaran. Salah satu faktor yang paling menentukan berhasilnya proses belajar mengajar sampai pada mutu pembelajaran di sekolah adalah Kepala Sekolah (Danim (2007:56).

Mutu adalah "gambaran dan karakteristik menyeluruh dari barang dan jasa yang menunjukkan kemampuannya dalam memuaskan kebutuhan yang diharapkan atau yang tersirat ( Kasmadi, 2003:24). Dalam konteks pendidikan, pengertian mutu mencakup input, proses, dan output pendidikan. Sedangkan pembelajaran adalah suatu proses dimana lingkungan seseorang secara sengaja dikelola untuk memungkinkan ia turut serta dalam tingkah laku tertentu dalam kondisi- kondisi khusus atau menghasilkan respons terhadap situasi tertentu (Sagala, 2003:61).

Kepala Sekolah dalam meningkatkan mutu pembelajaran harus memperhatikan dua hal yaitu pertama, dalam proses pembelajaran melibatkan proses berpikir. Kedua, dalam proses pembelajaran membangun suasana dialogis dan proses tanya jawab terus menerus yang diarahkan untuk memperbaiki dan meningkatkan kemampuan berpikir peserta didik yang pada gilirannya kemampuan berpikir itu dapat membantu peserta didik untuk memperoleh pengetahuan yang mereka konstruksi sendiri (Mulyasa, 2004:79). Strategi yang dapat dilakukan oleh Kepala Sekolah (Mulyasa, 2004:63) dalam meningkatkan mutu pembelajaran melalui komponen antara lain :

1. Memotivasi guru untuk kreatif dan inovatif dalam proses belajar mengajar

2. Mengikutkan guru dalam kegiatan pelatihan, workshop, seminar dan lain sebagainya

3. Menekankan kedisiplinan

4. Melakukan supervisi

5. Penambahan jam pelajaran

Menurut Muljono (2006:29), mutu pembelajaran memiliki lima indikator (ciri) yaitu sebagai berikut :

1. Kesesuaian

Kesesuaian yaitu antara karakteristik peserta didik dengan strategi belajar

2. Daya tarik,

Daya tarik guru dalam menciptakan suasana kelas yang akrab hangat dan merangsang pembentukan kepribadian peserta didik.

3. Efektivitas

Efektivitas dalam pembelajaran melalui tahap perencanaan, pengembangan, pelaksanaan, penilaian dan penyempurnaan.

4. Efisiensi dan

Efisiensi kesepadanan antara waktu, biaya, dan tenaga yang digunakan dengan hasil yang diperoleh.

5. Produktivitas pembelajaran

Produktivitas pembelajaran dari menghafal dan mengingat ke menganalisis dan mencipta.

Berdasarkan uraian di atas dapat dipahami bahwa mutu pembelajaran sangat berkaitan erat dengan guru sebagai subjek yang langsung berkaitan dengan proses belajar mengajar. Bermula dari proses inilah akan dapat diketahui seberapa besar tingkat mutu pembelajaran bahkan pendidikan di Indonesia. Programme for International Study Assessment (PISA) 2012 menempatkan Indonesia sebagai salah satu negara dengan peringkat terendah dalam pencapaian mutu pendidikan (Tempo/06/12/2013). Menurut data dari UNESCO pendidikan di Indonesia 
menempati peringkat ke-10 dari 14 negara berkembang. Sedangkan komponen penting dalam pendidikan yaitu para guru menempati urutan ke-14 dari 14 negara berkembang di dunia.

(https://www.taralite.com/artikel/post/kualitas -pendidikan-indonesia-di-mata-dunia).

Berdasarkan data tersebut menarik untuk diungkapkan bagaimanakah strategi yang dilakukan oleh kepala sekolah sebagai pemimpin dalam sebuah lembaga pendidikan. Propinsi lampung sebagai salah satu propinsi di Indonesia masih berada pada peringkat 27 di tingkat nasional kaitanya dengan mutu pendidikannya (Harian Lampung. 15/12/2016). Lembaga Penjamin Mutu Pendidikan (LPMP) Lampung merilis tahun ini Lampung menduduki peringkat 16 besar Ujian Kompetensi Guru (UKG) dari 34 provinsi penyelenggara UKG. Nilai ini mengalami peningkatan dati tahun sebelumnya yang hanya berada pada tingkat 20 nasional. Adapaun nilai rata-rata nilai UKG untuk Lampung adalah sebesar 53.36 (Tribun Lampung, 11/02/2017). Oleh karena itu dalam penelitian ini ingin mengungkapkan bagaimana strategi Kepala Sekolah dalam meningkatkan mutu pembelajaran di SMP Nurul Islam Kelurahan Garuntang Kecamatan Bumi Waras Kota Bandar Lampung.

\section{B. Tujuan}

Penelitian ini bertujuan untuk mengetahui strategi Kepala Sekolah dalam meningkatkan mutu pembelajaran di SMP Nurul Islam Kelurahan Garuntang Kecamatan Bumi Waras Kota Bandar Lampung.

\section{Metode}

Penelitian ini menggunakan pendekatan diskriptif kualitatif sedangkan bentuk penelitianya adalah penelitian lapangan (field research. Lokasi penelitianya yaitu di SMP Nurul Islam Kelurahan Garuntang Kecamatan Bumi Waras Kota Bandar Lampung. Objek penelitianya adalah seluruh guru yang ada di SMP Nurul Islam beserta kepala sekolah.

Metode pengumpulan data yang digunakan adalah observsi, interview atau wawancara, serta dokumentasi. Tahapan analisis data yaitu melakukan reduksi data, display data kemudian menarik kesimpulan (verifikasi data).

\section{Pembahasan}

SMP Nurul Islamn Garuntang Kecamatan Bumi Waras Kota Bandar Lampung pertama kali berdiri pada tahun 1983, kepala sekolah pertama adalah A. Busro Mazace, BA sampai dengan tahun 1986. Kemudian digantikan oleh Syarif Taruna sampai dengan tahun 1983, kemudian digantikan lagi oleh Busro Masace sampai dengan sekarang (Busro, wawancara 16 Mei 2016). Sekolah ini dulu terletak di Jalan Yos Sudarso Gang Ikan Kacangan No. 6 Sukaraja Bandar Lampung kemudian pindah di Jalan Gatot Subroto gang Payakun Garuntang Kota Bandar Lampung.

Visi SMP Nurul Islamn Garuntang Kecamatan Bumi Waras Kota Bandar Lampung adalah mencerdaskan dan meningkatkan keimanan warga sekolah serta menjadikan manusia yang berkualitas sehingga mampu menghadapi tantangan zaman yang selalu berubah. Sedangkan misinya adalah :

a. Meningkatkan profesionalisme guru dan pegawai

b. Meningkatkan prestasi dalam bidang akademik dan non akademik

c. Menciptakan kegiatan belajar yang inovatif, kreatif dan menyenangkan

d. Meningkatkan kegiatan ekstrakulikuler secara optimal

e. Meningkatkan intlektual peserta didik, sehingga memiliki daya saing yang tinggi dalam segala bidang

f. Menjadikan peserta didik yang memiliki akhlakul karimah dan bertaqwa

g. Menciptakan suasana madrasah yang kondusip dan bernuangsa Islami.

Berdasarkan hasil observasi dan wawancara yang telah peneliti lakukan di SMP Nurul Islam Kelurahan Garuntang Kecamatan Bumi Waras Kota Bandar Lampung bahwa peran guru Pendidikan Agama Islam dalam meningkatkan mutu pembelajaran Pendidikan Agama Islam Pendidikan Agama Islam adalah :

1. Memotivasi guru untuk kreatif dan inovatif dalam mengajar

Peningkatan mutu pembelajaran bukan persoalan yang mudah dilakukan. Butuh motivasi dan dukungan dari berbagai pihak, seperti halnya motivasi dari kepala sekolah. Seperti yang diungkapkan oleh Ibu Rosnani, S. Pd. I selaku guru Pendidikan Agama Islam yang mengatakan bahwa "Dorongan motivasi dan juga perhatian dari Kepala Sekolah memberi semangat kepada para guru, untuk lebih kreatif dan inovatif dalam pembelajaran di kelas, 
memberikan reward kepada guru yang berprestasi selain itu kita juga diberi kenaikan gaji meskipun sedikit tetapi itu dapat memotivasi kami" (Rosnani, Wawancara, Mei 2016).

Adapun bentuk kreativitas dan inovasi guru Pendidikan Agama Islam dalam mengajar (Rosnani, Wawancara, Mei 2016), tergambar dalam wawancara dibawah ini :

"Bentuk kreativitas dan inovasi yang saya lakukan dalam proses pembelajaran Pendidikan Agama Islam dalah kreativitas dalam mengelola kelas. Manajemen kelas merupakan aktifitas guru dalam mengelola dinamika kelas, mengorganisasikan sumber daya yang ada serta menyusun perencanaan aktifitas yang dilakukan di kelas untuk diarahkan dalam proses pembelajaran yang baik. Dalam hal manajemen kelas, kreativitas guru dalam manajemen kelas diarahkan untuk membantu siswa di kelas dapat belajar secara kolaboratif dan kooperatif dan menciptakan lingkungan akademik yang kondusif dalam proses belajar. Selain itu melakukan kreativitas dalam penggunaan media pembelajaran yang merupakan alat atau benda yang dapat mendukung proses pembelajaran di kelas untuk membantu siswa dalam memahami konsep abstrak yang diajarkan, meningkatkan motivasi siswa dalam belajar, mengurangi terjadinya mis understanding, dan memotivasi guru untuk mengembangkan pengetahuan.

2. Mengikutkan pelatihan, workshop maupun seminar kepada para guru

Berdasarkan hasil wawancara yang telah peneliti lakukan dengan ibu Dhianingsih, S. Pd. I, (Mei 2016), menyatakan bahwa dirinya aktif mengikuti musyawarah yang dilakukan pihak sekolah baik diawal tahun ajaran baru, pertengahan dan akhir ajaran yang bertujuan untuk menyatukan visi dan misi sekolah dalam rangka peningkatan mutu pembelajaran dan pernah mengikuti pendikan pelatihan diklat guru di luar sekolah misalnya pada awal memasuki tahun ajaran baru diadakan pelatihan tentang strategi pembelajaran dan PTK (Penelitian Tindakan Kelas) yang diadakan oleh Dinas Pendidikan dan Kebudayaan Kabupaten Tanggamus dan pernah juga mengikuti seminar tentang peingkatan kualitas sumber daya guru yang diselenggarakan oleh
Dinas Pendidikan dan Kebudayaan Provinsi Lampung.

Hal ini sejalan dengan yang diungkapkan oleh Bapak Muhadi, S. Pd.I (Mei 2016) bahwa dalam rangka meningkatkan kualitas pengembangan sumber daya manusia, saya pernah mengikuti seminar yang diadakan oleh Kementerian Agama Kabupaten Tanggamus. Selain itu juga aktif mengikuti kegiatan MGMP yang dilakukan setiap satu bulan sekali yang bertujuan untuk meningkatkan silaturrahim diantara guru pendidikan Agama Islam juga untuk bertukar pikiran dan menambah wawasan bidang pendidikan.

Pernyataan guru Pendidikan Agama Islam tersebut di atas diperkuat juga oleh pernyataan Kepala Sekolah SMP Nurul Islam Kelurahan Garuntang Kecamatan Bumi Waras Kota Bandar Lampung, yang mengatakan bahwa setiap tahun ajaran baru, pertengahan akhir ajaran kami selalu mengadakan musyawarah tentang strategi pembelajaran. Tujuan pelatihan ini speran guru mempunyai wawasan baru, dengan bertambahnya pengetahuan maka nantinya akan berdampak pada pelayanan kepada peserta didik. Selain itu, saya selaku kepala sekolah merekomendasikan guru-guru untuk mengikuti forum MGMP (Musyawarah Guru Mata Pelajaran) tujuannya agar terjadi sharing antar guru bidang studi se Kecamatan Bumi Waras (Muldjono, Wawancara, Mei 2016).

Pendapat Bapak Pudji Muljono juga diperkuat oleh Bapak Asep Sutisna, selaku waka kurikulum mengatakan, bahwa:

"Banyak sekali pelatihan yang dilakukan misalnya tentang kurikulum, strategi pembelajaran, PTK dan lainnya, tiap ada undangan baik untuk guru bidang studi maupun yang lain, guru selalu diikutkan. Ya, sesuai dengan permintaan yang memberi undangan ditujukan pada guru dibidang apa. Tapi kalau tempatnya di sekolah sendiri semua guru diusahakan ikut semua".

Uraian di atas mempertegas bahwa peningkatan kompetensi guru dapat dilakukan melalui program pelatihan dalam jabatan (in service training). Pelatihan mengandung makna bahwa setelah mengikuti pelatihan guru akan terdorong motivasinya untuk memperbaiki kinerja, cara pembelajaran atau penyegaran ilmu dan informasinya. Sedangkan tujuan mengikuti pelatihan, seminar dan sebagainya adalah untuk penambahan pengetahuan, keterampilan, dan perbaikan sikap dari peserta pelatihan, pengembangan penampilan kerja invidu dan pengembangan karir seseorang. Dengan adanya pelatihan-pelatihan yang diikuti oleh guru-guru, 
diharapkan guru akan lebih paham dengan dunia kerja, dapat mengembangkan kepribadiannya, penampilan kerja individu, mengembangkan karir, perilakunya menjadi efektif dan guru akan menjadi lebih berkompeten.

\section{Menekankan kedisiplinan}

Guru di SMP Nurul Islam Kelurahan Garuntang Kecamatan Bumi Waras Kota Bandar Lampung menyatakan bahwa ddirinya selalu mengedepankan kedisiplinan baik itu untuk peserta didik maupun untuk dirinya sendiri.

Berdasarkan observasi (Mei 2016), bentuk kedisiplinan yang dilakukan oleh Bapak dan Ibu guru dan lainnya selalu hadir di sekolah sebelum pelajaran dimulai yaitu biasanya sampai di sekolah jam 07.00. Tujuan kehadiran guru di sekolah lebih awal sebelum pelajaran dimulai adalah untuk memberikan keteladanan dan contoh kepada peserta didik tentang kedisiplinan waktu yang diharapkan dapat dicontoh oleh seluruh peserta didik.

Hasil observasi tersebut di atas diperkuat dengan pernyataan Kepala Sekolah (Muldjono, Wawancara, Mei 2016) yang menyatakan bahwa :

"Sesuai dengan peraturan yang telah diberlakukan di SMP Nurul Islam Kelurahan Garuntang Kecamatan Bumi Waras Kota Bandar Lampung bahwa jam masuk sekolah jam 07.15-13.30 WIB. Guru Pendidikan Agama Islam merupakan salah satu guru yang aktif datang ke sekolah selalu lebih awal kira-kira 15 menit sebelum jam pelajaran dimulai, tata tertib ini lebih dikhususkan pada guru yang mengajar pada jam pelajaran pertama".

Pernyataan di atas dikuatkan oleh Reinata peserta didik kelas VII (wawancara, mei 2016) menuturkan bahwa:

"Guru Pendidikan Agama Islam di SMP Nurul Islam Kelurahan Garuntang Kecamatan Bumi Waras Kota Bandar Lampung ini sangat mengedepankan kedisiplinan, misalnya pada saat beliau masuk pada jam pertama pelajaran, beliau selalu mengawasi peserta didik untuk berbaris di depan sebelum masuk kelas dan pada saat masuk ke dalam kelas seluruh peserta didik untuk bersalaman, kalau ada peserta didik yang terlambat selalu menegurnya agar tidak terlambat lagi...".

Setiap masuk kelas, Bapak Pudji Muljono selalu memonitoring peserta didik yang terlambat masuk sekolah, peserta didik yang terlambat diserahkan kepada tatib yang nantinya akan dicatat di dalam buku CAKEP (Catatan Kepribadian). Langkah awal jika ada peserta didik yang sering tidak masuk sekolah beliau berkoordinasi dengan guru Bimbingan dan Konseling dan Kepala Sekolah untuk memberi peringatan pada peserta didik tersebut, jika teguran itu tidak dihiraukan maka pihak sekolah akan memanggil orang tua peserta didik untuk menghadap guru Bimbingan dan Konseling dan apabila tidak dapat diselesaikan maka akan diselesaikan oleh kepala sekolah.

Adapun bentuk kedisiplinan yang diterapkan oleh guru di SMP Nurul Islam Kelurahan Garuntang Kecamatan Bumi Waras Kota Bandar Lampung adalah :

a. Disiplin terhadap pemanfaatan waktu Bapak Suhadi Efendi, S. Pd. selaku guru Bahasa Inggris di SMP Nurul Islam Kelurahan Garuntang Kecamatan Bumi Waras Kota Bandar Lampung menyatakan bahwa salah satu masalah yang sering dihadapi oleh pelajar atau siswa adalah banyak pelajar atau siswa yang mengeluh kekuragan waktu untuk belajarnya, tetapi mereka sebenarnya kurang memiliki keteraturan dan disiplin untuk mempergunakan waktu secara efisien. Banyak waktu yang terbuangbuang disebabkan karna mengobrol omongan-omongan yang tidak habishabisnnya. Menanggapi hal itu sekolah membuat berbagai himbauan agar siswa lebih baik berada di perpustakaan dan melakukan diskusi pelajaran ketika berda di luar kelas.

Kepala sekolah juga selalu melakukan kontrol terhadap jam kegiatan belajar yang ada di sekolah, menasehati bahkan menegur guru yang tidak menggunakan jam belajar sesuai dengan jadwalnya.

b. Disiplin mengerjakan tugas rumah Ibu Rita Silviana, S. Pd. selalu guru IPA di SMP Nurul Islam Kelurahan Garuntang Kecamatan Bumi Waras Kota Bandar Lampung menyatakan bahwa salah satu prinsip belajar adalah ulangan dan latihan. Dalam proses belajar tahapan ini wajib ada dan dilaksanakan oleh setiap guru. Kepala sekolah dalam kurun 2 minggu selalu melakukan monitoring tentang tugas atau latihan yang telah diberikan oleh guru kepada siswa.

c. Disiplin terhadap tata tertib

Ibu Sumiati, S. Pd., selaku guru IPS di SMP Nurul Islam Kelurahan Garuntang Kecamatan Bumi Waras 
Kota Bandar Lampung menyatakan bahwa didalam proses balajar mengajar, disiplin terhadap tata tertib sangat penting untuk diterapkan, karna dalam suatu sekolah tidak memiliki tata tertib maka proses belajar mengajar tidak akan berjalan dengan lancar sesuai dengan rencana. Antara peraturan dan tata tertib merupakan suatu kesatuan yang tidak dapat dipisahkan sebagai pembentukan disiplin siswa dalam mentaati peraturan di dalam kelas maupun diluar kelas (wawancara, Mei 2016).

Untuk melakukan disiplin terhadap tata tertib dengan baik, maka guru bertanggung jawab menyampaikan dan mengontrol berlakunya peraturan dan tata tertib tersebut. Dalam hal ini staf sekolah atau guru perlu terjalinnya kerja sama sehingga tercipta disiplin kelas dan tata tertip kelas yang baik tampa adanya kerja sama tersebut dalam pembinaan disiplin sekolah maka akan terjadi pelanggaran terhadap peraturan dan tata tertip sekolah serta terciptanya suasana balajar yang tidak diinginkan. Dengan demikian untuk terciptanya disiplin yang harmonis dan terciptanya disiplin dari siswa dalam rangka pelaksanaan peraturan dan tata tertib dengan baik, maka di dalam suatu lambaga atau lingkungan sekolah perlu menetapkan sikap disiplin terhadapsiswa, agar tercipta proses belajar mengajar yang baik.

d. Melakukan supervisi

Kegiatan utama pendidikan di sekolah dalam rangka mewujudkan tujuannya adalah kegiatan pembelajaran, sehingga seluruh aktivitas sekolah bermuara pada pencapaian efisiensi dan efektivitas pembelajaran. Oleh karena itu, salah satu strategi Kepala Sekolah adalah sebagai supervisor yaitu, mensupervisi pekerjaan yang dilakukan oleh tenaga kependidikan.

Bapak Pudji Muljono menyatakan (wawancara, Mei 2016), bahwa selalu melakukan supervisi kepada para guru khususnya dalam penyusunan perangkat pembelajaran setiap memasuki awal sementer untuk melihat apakah perangkat pembelahjaran yang disusun oleh guru sudah benar atau belum, jika terdapat kesalahan maka dirinya langsung memberikan bimbingan dan arahan.
Hal di atas dilakukan oleh Kepala SMP Nurul Islam Kelurahan Garuntang Kecamatan Bumi Waras Kota Bandar Lampung mengingat begitu pentingnya perangkat pembelajaran dalam proses belajar mengajar, saya sebagai Kepala Madrasah setiap tahun khususnya setiap awal semester selalu membimbing dan memberi petunjuk tentang bagaimana cara merumuskan dan membuat berbagai perangkat pembelajaran seperti Rencana Pelaksanaan Pembelajaran (RPP), silabus, program tahunan, program semester, program bulanan, program mingguan, perumusan alokasi waktu pembelajaran, perumusan dalam menetapkan kriteria ketuntasan minimal (KKM) bahkan sampai dengan analisis ulangan harian, analisis ulangan tengah semester, analisis ulangan semester dan lain sebagainya.

Langkah ini menurut Kepala Sekolah bertujuan agar para guru memiliki pengetahuan dan wawasan tentang penyusunan berbagai perangkat pendidikan yang sesuai dengan kurikulum yang berlaku, sehingga apa yang dilakukan oleh guru tidak menyimpang dari koridor peraturan yang berlaku. Apa yang dilakukan oleh Kepala Sekolah tersebut dibenarkan oleh salah satu guru di SMP Nurul Islam Kelurahan Garuntang Kecamatan Bumi Waras Kota Bandar Lampung (Muhtar Sofian, wawancara, Mei 2016), yang menyatakan sebagai berikut :

"Kepala Sekolah selalu melakukan supervisi kepada para guru baik dalam hal penyusunan perankat pembelajaran maupun pengawasan langsung pada saat proses pembelajaran di kelas, hal ini menurut saya bertujuan untuk membina guru-guru untuk lebih memahami tujuan umum pendidikan. Dengan demikian agar menghilangkan anggapan tentang adanya mata pelajaran/bidang studi, sehingga setiap guru mata pelajaran dapat mengajar dan mencapai prestasi maksimal bagi peserta didiknya, membina guru-guru guna mengatasi problem-problem peserta didik demi kemajuan prestasi belajarnya, membina 
guru-guru dalam meningkatkan kemampuan mengevaluasi, mendiagnosa kesulitan belajar dan seterusnya.

e. Penambahan Jam Pelajaran

Pada umumnya mata pelajaran yang diberikan di SMP Nurul Islam Kelurahan Garuntang Kecamatan Bumi Waras Kota Bandar Lampung dua jam pelajaran kecuali untuk mata pelajaran Matematika, Bahasa Indnesia dan IPA dengan alokasi 3 jam mata pelajaran. Akan tetapi khusus untuk mata pelajaran Pendidikan Agama Islam diberikan selama tiga jam pelajaran, yaitu dua jam mengikuti kurikulum dan yang satu jam kebijakan dari kepala sekolah, karena materi Pendidikan Agama Islam sangat luas dan berat. Seperti yang dipaparkan Kepala Sekolah SMP Nurul Islam Kelurahan Garuntang Kecamatan Bumi Waras Kota Bandar Lampung bahwa:

"Materi pelajaran Pendidikan Agama Islam itu sangat berat dan susah, saya rasa kalau waktu yang hanya dua jam pelajaran saya rasa tidak cukup atau kurang mengena, maka saya selaku pimpinan di SMP Nurul Islam Kelurahan Garuntang Kecamatan Bumi Waras Kota Bandar Lampung memberi kebijakan untuk penambahan jam pelajaran khusus Pendidikan Agama Islam, yang dua jam pelajaran itu mengikuti kurikulum dan yang satu jam itu dikhususkan pada praktek".

Pernyataan tersebut sama halnya dengan yang dikatakan oleh Ibu Rosnani, S. Pd. I. selaku guru Pendidikan Agama Islam, bahwa:

"memang betul, di SMP Nurul Islam Kelurahan Garuntang Kecamatan Bumi Waras Kota Bandar Lampung ini khusus mata pelajaran Pendidikan Agama Islam ada 3 jam pelajaran, yang 2 jam itu mengikuti kurikulum dan yang satu jam itu kebijakan dari kepala sekolah. Dengan adanya penambahan jam pelajaran maka guru Bahasa Arab diharapkan dapat melaksanakan tugasnya dengan baik".
Dengan adanya kebijakan dari kepala sekolah yaitu penambahan 1 jam pelajaran Pendidikan Agama Islam, maka guru diharapkan bisa menguasai materi serta bisa mengembangkannya agar menghasilkan lulusan yang berkualitas, yang nantinya akan meningkatkan mutu pembelajaran.

Kaitannya dengan peran pengembangan pengamalan keagamaan juga dilakukanya kegiatan keagamaan yang dinamakan Rohani Islam (Rohis) yang mana Rohis ini adalah bagian kinerja dari OSIS pada bidang keagamaan yang memiliki fungsi dan peran tersendiri, hal ini terlihat pada program kerja Rohani Islam dan kegiatan yang ada. Sebagaimana pernyataan Ibu Rosnani selaku guru Pendidikan Agama Islam bahwa selain pembelajaran di kelas, peningkatan mutu pembelajaran Pendidikan Agama Islam juga dilakukan melalui kegiatan ekstrakulikuler yang dikenal dengan Rohani Islam, kegiatan ini langsung dibina oleh guru yang ada di SMP Nurul Islam Kelurahan Garuntang Kecamatan Bumi Waras Kota Bandar Lampung ini bentuk kegiatan Rohani Islam ini sangat menonjol pas hari Jum'at, karena pas hari itu mulai pagi ketika akan memulai pelajaran yasinan yang dipusatkan di kantor waka dipandu guru, kemudian kegiatan shalat Jum'at dan masih banyak lagi bentuk kegiatan Rohani Islam. Hal ini di kuatkan dengan penuturan dari Kepala Sekolah yang juga sebagai pembina Rohani Islam (Rohis), yiatu:

"Kalau hari Jumat ada kebijakan dari kepala sekolah untuk kegiatan shalat Jum'at dan kajian setelah shalat Jum'at yang dibina langsung oleh guru, kadang juga guru-guru dari bidang studi lain yang memberikan kajian".

Kegiatan Rohani Islam ini pelaksanaannya tidak serta merta berjalan sendiri, akan tetapi membutuhkan dukungan dan dorongan seluruh tenaga pendidik yang ada. Untuk itu fungsi guru Pendidikan Agama Islam yang ada di SMP Nurul Islam Kelurahan Garuntang Kecamatan Bumi Waras Kota Bandar Lampung ini selain sebagai guru pengajar di kelas, juga memfungsikan dirinya sebagai fasilitator dan mediator sekaligus penanggung jawab atas 
kegiatan yang dilaksanakan oleh Rohani Islam.

Berdasarkan wawancara secara langsung dengan kepala sekolah, dan guru Pendidikan Agama Islam di SMP Nurul Islam Kelurahan Garuntang Kecamatan Bumi Waras Kota Bandar Lampung dan juga menurut pengamatan peneliti melalui observasi secara langsung. Dapat dipaparkan bahwa guru sebagai profesi berarti guru sebagai pekerjaan yang mensyaratkan kompetensi (keahlian dan kewenangan dalam pendidikan dan pembelajaran agar dapat melaksanakan pekerjaannya secara efektif dan efisien.

Kinerja guru perlu ditingkatkan hal ini dimaksud untuk mengimbangi dunia pendidikan yang semakin maju. Guru yang profesional adalah pendidik yang mempunyai potensi akademik, latar belakang pendidikan yang tinggi dan kreatif serta inovatif dalam pembelajaran. Hal ini senada dengan yang diungkapkan oleh Kepala Sekolah, bahwa:

"guru yang profesional itu dilihat dari segi akademiknya, latar belakang pendidikannya sampai tingkat mana, ya paling tidak harus S1, performennya misalnya cara berpakaian, cara berbicara bagaimana tutur katanya dari ia berbicara kita bisa menilai apakah guru itu punya potensi dalam mengajar apa tidak. Dilihat dari intelegensinya nilai IPKnya paling tidak di atas tiga, stake holder, bagaimana ia menangani peserta didik, kreatif, dan inovatif serta ketrampilan lainnya".

Dalam rangka meningkatkan mutu pembelajaran di SMP Nurul Islam Kelurahan Garuntang Kecamatan Bumi Waras Kota Bandar Lampung, para guru sudah dilaksanakan dengan baik. Hal ini senada dengan yang diungkapkan oleh Wakil Kepala Sekolah SMP Nurul Islam Kelurahan Garuntang Kecamatan Bumi Waras Kota Bandar Lampung bidang kurikulum yaitu bapak Asep Sutisna, bahwa respon dan kinerja guru disini dalam melaksanakan strategi saya rasa sudah baik, ini dibuktikan dengan persiapan guru dengan membuat RPP, modul pembelajaran serta metode dalam pembelajaran di tahun ajaran baru guru harus membuat prota (program tahunan), begitupun juga setiap semesster guru membuat promes (program semester) dan silabus.

Dalam rangka meningkatkan mutu pembelajaran Pendidikan Agama Islam yang baik, guru sebagai seorang pendidik yang professional dan menempatkan guru sebagai fungsional transfer ilmu pengetahuan kepada anak didiknya dalam proses belajar mengajar meliputi: kognitif, afektif dan psikomotorik, maka guru sebagai fasilitator harus membuat dan menyiapkan bahan ajar sebelum melaksanakan kegiatan belajar mengajar sesuai dengan kurikulum yang digunakan di sekolah.

Guru Pendidikan Agama Islam di SMP Nurul Islam Kelurahan Garuntang Kecamatan Bumi Waras Kota Bandar Lampung dari segi kompetensi pendidikannya bisa dikatakan professional. Hal ini terbukti dengan kualifikasi tenaga pendidikan yang sudah kualifait. Tidak hanya itu, guru yang mengajar di SMP Nurul Islam Kelurahan Garuntang Kecamatan Bumi Waras Kota Bandar Lampung sudah menerapkan metode pembelajaran sesuai dengan kurikulum yang berlaku.

Umumnya guru Pendidikan Agama Islam menggunakan berbagai variasi metode pembelajaran dengan tujuan agar peserta didik tidak jenuh terhadap pembelajaran yang sedang dilaksanakan, dan guru selalu membuat RPP dan modul pembelajaran sebelum mulai mengajar di kelas. Demi kelancaran proses belajar mengajar tugas guru tidak hanya membuat administrasi seperti yang telah terangkan di atas, guru harus mengkonsultasikan administrasi yang telah dibuat kepada waka kurikulum.

E. Penutup

Berdasarkan pembahsan di atas dapat disimpilkan bahwa Kepala Sekolah melakukan berbagai macam strategi dalam meningkatkan mutu pembelajaran di SMP Nurul Islam Kelurahan Garuntang Kecamatan Bumi Waras Kota Bandar Lampung dengan cara memotivasi guru untuk kreatif dan inovatif dalam proses belajar mengajar, mengikutkan guru dalam kegiatan pelatihan, workshop, seminar dan lain sebagainya untuk 
menambah pengetahuan dan wawasan guru dalam dunia pendidikan, menekankan kedisiplinan dari segi pemanfaatan waktu belajar, pembuatan perangkat pembelajaran maupun pakaian, melakukan supervisi (pengawasan) dalam hal penyusunan perangkat pembelajaran maupun dalam pelaksanaan pembelajaran di kelas dan penambahan jam pelajaran khusus untuk mata pelajaran Pendidikan Agama Islam karena materinya sangat luas.

\section{DAFTAR PUSTAKA}

E. Mulyasa, Menjadi Kepala Sekolah Profesional dalam Konteks Menyukseskan MBS dan $K B K$, (Bandung: Remaja Rosda Karya, 2005), cet. V, hal. 31 .

----, Memahami Tugas Kepala Sekolah sebagai Supervisi, (Jakarta: Gressindo, 2004), hal. 79

Hartono Kasmadi, Peningkatan Mutu Pembelajaran Pendidikan, (Bandung: Armico, 2003), hal. 24.

Pudji Muljono, Manajemen Pembelajaran Quantum Teaching, (Jakarta: Balai Pustaka, 2006), hal. 29.

Pudji Muljono, Manajemen Pembelajaran Quantum Teaching, (Jakarta: Balai Pustaka, 2006).

Sagala, Syaiful, Tinjauan Umum tentang Pembelajaran yang Efisien dan Efektif, (Jakarta: Pustaka Pelajar, 2003).

Syaiful Sagala, Tinjauan Umum tentang Pembelajaran yang Efisien dan Efektif, (Jakarta: Pustaka Pelajar, 2003), hal. 61

Tim Penyusun, Undang-undang Nomor 20 Tahun 2003 tentang Sistem Pendidikan Nasional, (Bandung: Citra Umbara, 2004), hal. 3

https://www.taralite.com/artikel/post/kualitaspendidikan-indonesia-di-mata-dunia, diunduh tanggal 26 oktober 2016.

https://m.tempo.co/read/news/2013/12/06/1735352 56/mutu-pendidikan-indonesia-terendah-didunia, diunduh tanggal 26 oktober 2016. 